\title{
The Role of Bole (Lake Soil) as a Mineral Supplement to Arsi- Bale Sheep Fed Natural Grass Hay and Concentrate Supplement
}

Belete Kuraz ${ }^{1}$, Adugna Tolera², Aster Abebe ${ }^{2}$

10.18805/ag.D-310

\begin{abstract}
Background: Mineral deficiencies are considered to be one of the nutritional constraints to sheep performance. An experiment was conducted to evaluate the role of bole soil on feed intake, live weight change and carcass characteristics of Arsi-Bale sheep fed natural grass hay and concentrate supplement and its cost-benefit analysis of bole soil supplementation.

Result: Total DM, OM, CP, NDF, ADF intake and ADL were higher $(p<0.0001)$ for T3 than for T1, T2 and T4. Final weight, body weight change, average daily gain and feed conversion efficiency were greater $(p<0.0001)$ for T3 and T2 than for T1 and T4. There were no differences ( $p>0.05)$ between T3 and T2 whereas T4 was greater than T1 in these variables. Slaughter weight (SW) was heavier $(p<0.0001)$ for treatment two and treatment three than for treatment four and treatment one, hot carcass weight, foreleg weight and dressing percentage on empty body weight basis were greater $(p<0.0001)$ for T3 and T2 than for T1 and T4.

Conclusion: Bole soil supplementation had potentially highest effect on feed intake, live weight change and carcass characteristics of Arsi-Bale sheep than non-supplemented groups. The present study also revealed that supplementation of minerals improved the total weight gain of sheep over the control treatment.
\end{abstract}

Key words: Bole soil, Carcass characteristics, Nutrient intake, Performance, Sheep, Supplementation.

\section{INTRODUCTION}

In rift valley parts of Ethiopia, sheep rearing has been hampered over the years mainly due to the absence of good quality and adequate feeds which contains sufficient minerals. During the dry season when both good quality and quantity forage is low what usually occurs sheep are loss of live weight, low birth weight, lower resistance to disease and poor fertility (Sisay et al., 2007). Mineral imbalance in soil and forages were considered responsible for low productive and reproductive performance of small ruminants in the tropics (McDowell, 2003). Mineral deficiencies are considered to be one of the nutritional constraints to animal productivity. Poor body condition, slow live weight gain, low fertility and high mortality are normally observed in mineral-deficient animals (McDowell et al., 1983; Vijchulata, 1995).

Different studies were so far conducted on the role of daily bole soil supplementation to small ruminants but, they are not enough to confirm its effect on live weight and feed intake of sheep. Though, those studies conducted to underline the importance of daily mineral supplementation to small ruminants in most part of the country; to date, the amount of daily bole soil supplementation to sheep and its cost benefit analysis has not been investigated in the study area so far. Moreover, attention has not been paid to its effect on Arsi-Bale sheep. The main objective of this study was, therefore, to evaluate the effect of bole soil supplementation in comparison to salt and commercial mineral mix on feed intake, live weight change and carcass characteristics of Arsi-Bale sheep and its cost benefit analysis.
${ }^{1}$ Department of Animal Science, Werabe University, P.O. Box 46, Werabe, Ethiopia.

${ }^{2}$ School of Animal Sciences, Hawassa University. P.O. Box 05, Hawassa, Ethiopia.

Corresponding Author: Belete Kuraz, Department of Animal Science, Werabe University, P.O. Box 46, Werabe, Ethiopia. Email: beleab2@gmail.com

How to cite this article: Kuraz, B., Tolera, A. and Abebe, A. (2021). The Role of Bole (Lake Soil) as a Mineral Supplement to Arsi-Bale Sheep Fed Natural Grass Hay and Concentrate Supplement. Agricultural Science Digest. 41(4): 638-643. DOI: 10.18805/ag.D-310. Submitted: 25-09-2020 Accepted: 03-12-2020 Online: 11-02-2021

\section{MATERIALS AND METHODS}

\section{Animals and management}

The study was conducted in Alage Agricultural Technical and Vocational Training College form March 15, 2015 to June 30, 2015. Twenty four males Arsi-Bale sheep with an average initial body weight of $14.05 \pm 1.12 \mathrm{~kg}$ (mean $\pm S D$ ) were used and randomized by weight assigned to four groups of six sheep each. Prior to commencement of the experiment, animals were kept for 15 days for adaptation and to observe their health status. They were housed in individual pens $(1 \mathrm{~m} \times 0.8 \mathrm{~m})$ in a well-ventilated concrete floor barn. All animals were drenched with a broad-spectrum antihelmentic and vaccinated against anthrax, pasteuriolosis and blackleg diseases. Bole soil was collected from Shalla Lake, Oromiya region. Sheep were offered ad libitum natural grass hay at $20 \%$ refusal rate adjusted every other week 
The Role of Bole (Lake Soil) as a Mineral Supplement to Arsi-Bale Sheep Fed Natural Grass Hay and Concentrate Supplement

and the supplemental minerals and concentrates throughout the experiment. Four treatment groups were randomly assigned to mineral supplementation.

$\mathrm{T} 1$ = Natural grass hay ad libitum $+300 \mathrm{~g} \mathrm{DM} / \mathrm{d}$ concentrate

+ no mineral supplement.

$\mathrm{T} 2=$ Natural grass hay ad libitum $+300 \mathrm{~g} \mathrm{DM} / \mathrm{d}$ concentrate $+1 \%$ salt.

T3 = Natural grass hay ad libitum $+300 \mathrm{~g} \mathrm{DM} / \mathrm{d}$ concentrate $+1 \%$ commercial mineral mix.

T4 = Natural grass hay ad libitum $+300 \mathrm{~g} \mathrm{DM} / \mathrm{d}$ concentrate $+2 \%$ bole soil.

Data of feed offered and refusals of the basal diet were recorded daily in the morning. The treatment diets were formulated on a DM basis. A randomized complete block design (RCBD) was used in the experiment.

\section{Feed intake}

Experimental sheep were fed for consecutive 90 days and offered natural grass hay free choice for ad libitum intake at $20 \%$ refusal rate where as the concentrate supplement was offered twice a day at 8.00 and $16.00 \mathrm{~h}$. The amounts of daily feed offered and refused were recorded to determine daily feed intake. Chemical composition of sub-samples of feed offered and refusal were analyzed and the results were used for calculation of daily dry matter and nutrient intake.

\section{Live weight change and feed conversion efficiency}

Data on live body weight change was taken every ten days after overnight fasting starting from the first day of the last acclimatization period using a suspended spring balance. Average daily weight gain for each sheep was determined as a difference between final and initial body weights divided by the total number of actual feeding days. Feed conversion efficiency (FCE), which is the measure of feed utilization, was determined by dividing daily average live weight gain by daily total DMI of the sheep as shown by Brown et al. (2001).

\section{Carcass analysis}

All animals were deprived of feed and water for $14 \mathrm{~h}$ to reduce variation in gut fill and were slaughtered to assess carcass characteristics of animals. Before slaughter, animals were weighed followed by slaughtering by cutting the jugular vein to drain blood. Esophagus was tied off close to head and the animals were suspended head down, over a container and blood was collected and weighed. The head was detached from the body and weighed without tongue when the main flow of blood ceased. Skin was flayed and weighed; forelegs and hind legs were trimmed off at carpal and tarsal joints and weighed. Entire gastrointestinal tract with contents were removed and weighed and then internal contents were emptied and the weight of the empty gut was recorded. After dressing and evisceration, carcass weight was immediately recorded to assess dressing percentage on slaughter weight and empty body weight bases. Empty body weight was calculated as slaughter weight without gut contents. Hot carcass weight was estimated after removing the weight of head, thoracic, abdominal and pelvic cavity contents as well as legs below the hock and knee joints. Rib-eye muscle area of each animal was determined by tracing the cross sectional areas between the $12^{\text {th }}$ and $13^{\text {th }}$ ribs after cutting perpendicular to the back bone (Purchas, 1978).

\section{Partial budget analysis}

It was calculated to determine profitability of all experimental feeds to sheep based on the procedure of Upton (1979). Net income (NI) was calculated by subtracting total variable cost (TVC) from total return (TR) as NI = TR-TVC. Change in net income $(\Delta \mathrm{NI})$ was calculated as a difference between change in total return $(\Delta T R)$ and change in total variable cost $(\Delta T V C)$, as : $\Delta \mathrm{NI}=\Delta \mathrm{TR}-\Delta \mathrm{TVC}$. The marginal rate of return (MRR) measures increase in net income $(\Delta \mathrm{NI})$ associated with each additional unit of expenditure ( $\triangle T V C)$. $M R R=\Delta N I / \Delta T V C$.

\section{Chemical analysis of feeds}

Samples of daily feed offered and refused were collected, weighed and separately stored for each animal in bags and kept in a room with adequate natural ventilation until the end of the experimental period. Then feed samples were thoroughly mixed, sub samples were taken to Hawassa University Nutrition Laboratory. The DM content of the feed was determined by drying the samples at $105^{\circ} \mathrm{C}$ overnight. Ash content of the sample was determined by combusting the samples at $550^{\circ} \mathrm{C}$ for $5 \mathrm{~h}$ in a muffle furnace. $\mathrm{N}$ content was determined using the Kjeldahl method and CP was calculated as $\mathrm{N} \% \times 6.25$ (AOAC, 1995). NDF contents were analyzed using the method of Van Soest et al. (1991) whereas, ADF and ADL contests were determined according to Van Soest and Robertson (1985) using ANKOM® 200 Fiber Analyzer. All samples were analyzed in duplicates. In regard to bole soil, mineral mix and salt were sampled and taken to the Debre Zeit laboratory. Macro minerals (Ca, P, $\mathrm{Mg}, \mathrm{K}, \mathrm{Na}$ and $\mathrm{S}$ ) and trace minerals (Mn, Cu, Fe and $\mathrm{Zn}$ ) were analyzed using the method of Mehlich (1984) in Mehlich 3 soil test extractant.

\section{Statistical analysis}

Data on feed intake, body weight change and carcass parameters were analyzed by analysis of variance (ANOVA) using the general linear model procedure of statistical analysis system software version 9.1(SAS, 2008). The treatment mean was separated by Duncan's multiple range test (DMRT), the model used for analysis of the data was:

$$
Y i j=\mu+t i+b j+e i j
$$

Where

$\mathrm{Y}=$ The response variable $\mu=$ Overall mean, $\mathrm{t} i=$ Treatment effect, bj = Block effect, eij=Random error.

\section{RESULTS AND DISCUSSION \\ Chemical composition of treatment feeds}

In agreement with a study of McDowell (2003) and McDonald et al. (2002), natural grass hay used as a basal diet in this study had low CP $(6.8 \%)$ and high fiber contents (Table 1). 
The Role of Bole (Lake Soil) as a Mineral Supplement to Arsi-Bale Sheep Fed Natural Grass Hay and Concentrate Supplement

Low CP content in this experiment may be due to stage of maturity at harvest and other environmental factors in which the hay was grown. The CP content of NSC in this study was relatively higher than the values documented by (Girma et al., 2014). The difference could be due to the method of processing (type of extractors in the extraction industries) and variety of the noug seed used.

Mineral content of bole soil used for the present study given in Table 2 was lower than the values reported by Shewangzaw et al. (2013) except for potassium and manganese. The contents of most minerals in bole used in the current study were lower than the values previously reported for bole soil from different Ethiopian Rift Valley Lakes (Nega et al., 2006; Adugna, 2008). This might be due to additional mixture of another type of soil, variations during mineral analysis, depth of soil sample taken and/or sampling time from different body parts of the Lakes.

\section{Feed intake of sheep}

In the current study, nutrient intake of mineral supplemented sheep was higher than non supplemented groups (Table 3). In a study of Hungate (1996) and Van Soest (1982) described that the micro flora in the digestive tract of sheep requires minerals in addition to nitrogen and energy sources feed to increase the rate of digestion and feed intake. In conformity with this Shirley (1986) stated that the lack of both major and trace minerals causes depression in feed intake.

\section{Body weight gain and feed conversion efficiency}

In line with a study of Sisay et al. (2007), sheep supplemented with bole soil (Table 4) were found to lose weight from the $2^{\text {nd }}$ to the $3^{\text {rd }}$ months of the experimental period followed by gain in the later period. Sheep in the control group had slower increase in body weight. This could be due to very low mineral intake from offered diet which is below the requirement of the sheep. The higher average daily gain and FCE for mineral supplemented group compared to the control group is consistent with the findings of Sisay et al. (2007) and Muluken et al. (2015).

\section{Carcass parameters}

In agreement with previous studies by White, (1992), Ranjbari and Rasti, (2000) and Fazlallah and Shahab (2015), slaughter

Table 1: Chemical composition of experimental feeds.

\begin{tabular}{lccccc}
\hline \multirow{2}{*}{ Experimental feeds } & OM & CP & NDF & ADF & ADL \\
\cline { 2 - 6 } & \multicolumn{5}{c}{ \%DM } \\
\hline Natural grass hay & 89.7 & 6.8 & 66.9 & 43.4 & 2.7 \\
Noug seed cake & 90.2 & 35.8 & 30.1 & 27.3 & 2.5 \\
Wheat bran & 95.2 & 16.4 & 36.4 & 15.7 & 1.7 \\
Natural grass hay refusal & & & & & \\
T1 & 91.3 & 4.1 & 76.6 & 49.7 & 3.5 \\
T2 & 91.7 & 3.5 & 71.7 & 53.1 & 3.9 \\
T3 & 91.4 & 3.2 & 77.2 & 44.6 & 3.6 \\
T4 & 91.2 & 3.9 & 75.7 & 50.9 & 3.9 \\
\hline T1
\end{tabular}

$\mathrm{T} 1=$ Grass hay refusal treatment $1, \mathrm{~T} 2=$ Grass hay refusal treatment 2, $\mathrm{T} 3=$ Grass hay refusal treatment 3 and $\mathrm{T} 4=$ Grass hay refusal treatment $4, \mathrm{DM}=$ Dry matter, $\mathrm{OM}=$ Organic matter, $\mathrm{CP}=$ Crude protein, NDF $=$ Neutral detergent fiber. $A D F=$ Acid detergent fiber, $A D L=$ Acid detergent lignin.

Table 2: Macro and micro mineral composition of mineral supplements.

\begin{tabular}{lccc}
\hline & \multicolumn{3}{c}{ Type of mineral supplement } \\
\cline { 2 - 4 } & Salt & Commercial mineral mix & Bole soil \\
\hline Macro minerals (\%) & & & \\
$\mathrm{Ca}$ & 0.15 & 3.14 & 0.62 \\
$\mathrm{P}$ & 0.002 & 0.02 & 0.02 \\
$\mathrm{Mg}$ & 0.01 & 0.06 & 0.01 \\
$\mathrm{~K}$ & 0.06 & 0.10 & 0.50 \\
$\mathrm{Na}$ & 34.2 & 0.40 & 5.62 \\
$\mathrm{~S}$ & 0.09 & 0.59 & 0.29 \\
Micro minerals (ppm) & & & \\
$\mathrm{Cu}$ & 0.83 & 2331.2 & 1.01 \\
$\mathrm{Fe}$ & 0.25 & 4704.5 & 63.97 \\
$\mathrm{Zn}$ & 0.47 & 2839.3 & 4.73 \\
$\mathrm{Mn}$ & 0.27 & 8745.3 & 71 \\
\hline
\end{tabular}

ppm $=$ Parts per million.

Table 3: Effect of supplementation of bole soil on dry matter and nutrient intake in growing Arsi-Bale sheep.

\begin{tabular}{|c|c|c|c|c|c|c|}
\hline \multirow{2}{*}{ Feed Intake $(\mathrm{g} / \mathrm{d})$} & \multicolumn{4}{|c|}{ Treatments } & \multirow{2}{*}{ SEM } & \multirow{2}{*}{$P$ value } \\
\hline & T1 & T2 & T3 & T4 & & \\
\hline Hay DMI & $348.1^{c}$ & $384.3^{b}$ & $415.1^{\mathrm{a}}$ & $355.8^{c}$ & 4.6 & $p<0.0001$ \\
\hline Concentrate DMI & 273.9 & 273.9 & 273.9 & 273.9 & 0.00 & ns \\
\hline Total DMI & $622^{d}$ & $658.2^{\mathrm{b}}$ & $689^{a}$ & $629.7^{c}$ & 5.1 & $p<0.0001$ \\
\hline Total OMI & $568.5^{d}$ & $644.2^{\mathrm{b}}$ & $663.5^{\mathrm{a}}$ & $607.5^{c}$ & 4.9 & $p<0.0001$ \\
\hline Total CPI & $86.3^{d}$ & $92.0^{\mathrm{b}}$ & $93.5^{\mathrm{a}}$ & $89.3^{c}$ & 0.4 & $p<0.0001$ \\
\hline Total NDFI & $326.8^{d}$ & $383.3^{\mathrm{b}}$ & $397.5^{\mathrm{a}}$ & $355.9^{c}$ & 3.7 & $p<0.0001$ \\
\hline Total ADFI & $204.6^{d}$ & $241.3^{b}$ & $250.5^{\mathrm{a}}$ & $223.5^{c}$ & 2.4 & $p<0.0001$ \\
\hline Total ADLI & $19.4^{\mathrm{d}}$ & $21.7^{\mathrm{b}}$ & $22.3^{a}$ & $20.6^{c}$ & 0.2 & $p<0.0001$ \\
\hline
\end{tabular}

$\mathrm{a}, \mathrm{b}, \mathrm{c}, \mathrm{d}$ Means with $\mathrm{P}<0.05$ values across rows are significantly different, $\mathrm{ns}=$ Non significantly different, $\mathrm{SEM}=\mathrm{Standard}$ error of mean, TDMI= Total dry matter intake, $\mathrm{CPI}=$ Crude protein intake, NDFI= Nutrient detergent fiber intake, ADFI= Acid detergent fiber intake, $\mathrm{ADLI}=$ Acid detergent lignin intake $\mathrm{T} 1=$ No mineral supplement, $\mathrm{T} 2=1 \%$ salt, $\mathrm{T} 3=1 \%$ commercial mineral mix and $\mathrm{T} 4=2 \%$ bole soil. 
The Role of Bole (Lake Soil) as a Mineral Supplement to Arsi-Bale Sheep Fed Natural Grass Hay and Concentrate Supplement

Table 4: Body weight and feed conversion efficiency in growing Arsi-Bale sheep supplemented with bole soil.

\begin{tabular}{lcccccr}
\hline \multirow{2}{*}{ Parameters } & \multicolumn{3}{c}{ Treatments } & \multirow{2}{*}{ SEM } & P value \\
\cline { 2 - 5 } & T1 & T2 & T3 & T4 & & \\
\hline Initial body weight $(\mathrm{kg})$ & 14.1 & 13.9 & 13.9 & 14.2 & 0.1 & $\mathrm{~ns}$ \\
Final body weight $(\mathrm{kg})$ & $16.0^{\mathrm{c}}$ & $19.9^{\mathrm{a}}$ & $20.1^{\mathrm{a}}$ & $18.1^{\mathrm{b}}$ & 1.2 & $\mathrm{p}<0.0001$ \\
Body weight change $(\mathrm{kg})$ & $1.9^{\mathrm{c}}$ & $6.0^{\mathrm{a}}$ & $6.1^{\mathrm{a}}$ & $3.9^{\mathrm{b}}$ & 0.9 & $\mathrm{p}<0.0001$ \\
Average daily gain $(\mathrm{g})$ & $21.7^{\mathrm{c}}$ & $63.8^{\mathrm{a}}$ & $68.3^{\mathrm{a}}$ & $45.9^{\mathrm{b}}$ & 1.3 & $\mathrm{p}<0.0001$ \\
FCE (g ADG/g TDMI) & $0.03^{\mathrm{c}}$ & $0.09^{\mathrm{a}}$ & $0.09^{\mathrm{a}}$ & $0.07^{\mathrm{b}}$ & 0.002 & $\mathrm{p}<0.0001$ \\
\hline
\end{tabular}

a, b, c Means with $\mathrm{P}<0.05$ values across rows are significantly different $\mathrm{ns}=$ Non significantly different, $\mathrm{SEM}=$ Standard error of mean, $\mathrm{FCE}=$ Feed conversion efficiency, $\mathrm{TDMI}=$ Total dry matter intake, $\mathrm{ADG}=$ Average daily gain, $\mathrm{SEM}=$ Standard error of mean, $\mathrm{T} 1=\mathrm{No}$ mineral supplement, $\mathrm{T} 2=1 \%$ salt, $\mathrm{T} 3=1 \%$ mineral mix and $\mathrm{T} 4=2 \%$ bole soil.

Table 5: Effect of bole soil supplementation on carcass characteristics in growing Arsi-Bale sheep.

\begin{tabular}{lcccccc}
\hline \multirow{2}{*}{ Carcass parameters } & \multicolumn{3}{c}{ Treatments } & \multirow{2}{*}{ SEM } & \multirow{2}{*}{$\mathrm{P}$ value } \\
\cline { 2 - 5 } & $\mathrm{T} 1$ & $\mathrm{~T} 2$ & $\mathrm{~T} 3$ & $\mathrm{~T} 4$ & & \\
\hline Fore leg $(\mathrm{kg})$ & $1.5^{\mathrm{c}}$ & $1.8^{\mathrm{a}}$ & $1.9^{\mathrm{a}}$ & $1.6^{\mathrm{b}}$ & 46.8 & $\mathrm{p}<0.0001$ \\
Hind leg (kg) & $1.6^{\mathrm{c}}$ & $1.9^{\mathrm{b}}$ & $2.2^{\mathrm{a}}$ & $1.8^{\mathrm{b}}$ & 42.6 & $\mathrm{p}<0.0001$ \\
Sternum (g) & $338.3^{\mathrm{c}}$ & $435.2^{\mathrm{b}}$ & $512.4^{\mathrm{a}}$ & $454.7^{\mathrm{b}}$ & 9.9 & $\mathrm{p}<0.0001$ \\
Slaughter body weight $(\mathrm{kg})$ & $16.0^{\mathrm{c}}$ & $19.9^{\mathrm{a}}$ & $20.1^{\mathrm{a}}$ & $18.1^{\mathrm{b}}$ & 441.4 & $\mathrm{p}<0.0001$ \\
Empty body weight $(\mathrm{kg})$ & $11.9^{\mathrm{b}}$ & $14.0^{\mathrm{a}}$ & $13.9^{\mathrm{a}}$ & $13.49^{\mathrm{a}}$ & 411.2 & $\mathrm{P}<0.05$ \\
Hot carcass weight $(\mathrm{kg})$ & $5.0^{\mathrm{c}}$ & $7.2^{\mathrm{a}}$ & $7.3^{\mathrm{a}}$ & $6.1^{\mathrm{b}}$ & 0.22 & $\mathrm{p}<0.0001$ \\
Dressing percentage $(\%)$ & & & & & \\
On empty body weight base & $41.9^{\mathrm{c}}$ & $51.8^{\mathrm{a}}$ & $52.4^{\mathrm{a}}$ & $45.4^{\mathrm{b}}$ & 0.8 & $\mathrm{p}<0.0001$ \\
On slaughter body weight base & $45.7^{\mathrm{b}}$ & $49.9^{\mathrm{a}}$ & $51.2^{\mathrm{a}}$ & $46.2^{\mathrm{b}}$ & 0.72 & $\mathrm{P}<0.001$ \\
Rib eye area $\left(\mathrm{cm}^{2}\right)$ & $5.5^{\mathrm{c}}$ & $7.1^{\mathrm{a}}$ & $6.8^{\mathrm{ab}}$ & $6.5^{\mathrm{b}}$ & 0.2 & $\mathrm{p}<0.0001$ \\
\hline
\end{tabular}

a, b, ${ }^{\circ}$ Means with $\mathrm{P}<0.05$ values across rows are significantly different, $\mathrm{ns}=$ Non significantly different, $\mathrm{SEM}=\mathrm{Standard}$ error of mean, $\mathrm{T} 1=$ No mineral supplement, $\mathrm{T} 2=1 \%$ salt, $\mathrm{T} 3=1 \%$ mineral mix and $\mathrm{T} 4=2 \%$ bole soil.

Table 6: Total edible offals in growing Arsi-Bale sheep supplemented with bole soil.

\begin{tabular}{lcccccc}
\hline \multirow{2}{*}{ Edible offals $(\mathrm{g})$} & \multicolumn{3}{c}{ Treatments } & \multirow{2}{*}{ SEM } & P value \\
\cline { 2 - 5 } & $\mathrm{T} 1$ & $\mathrm{~T} 2$ & $\mathrm{~T} 3$ & $\mathrm{~T} 4$ & & \\
\hline Head & $966.1^{\mathrm{c}}$ & $1190.3^{\mathrm{a}}$ & $1171.2^{\mathrm{a}}$ & $1052.3^{\mathrm{b}}$ & 22.3 & $\mathrm{P}<0.0001$ \\
Tail & $381.3^{\mathrm{b}}$ & $456.2^{\mathrm{a}}$ & $492.12^{\mathrm{a}}$ & $479.24^{\mathrm{a}}$ & 13.98 & $\mathrm{P}<0.001$ \\
Tongue & $45.3^{\mathrm{b}}$ & $51.2^{\mathrm{a}}$ & $48.8^{\mathrm{a}}$ & $44.2^{\mathrm{b}}$ & 0.9 & $\mathrm{P}<0.001$ \\
Liver & $215.9^{\mathrm{b}}$ & $271.2^{\mathrm{a}}$ & $265.3^{\mathrm{a}}$ & $252.9^{\mathrm{a}}$ & 9.5 & $\mathrm{P}<0.05$ \\
Heart & $60.8^{\mathrm{c}}$ & $98.5^{\mathrm{b}}$ & $105.5^{\mathrm{a}}$ & $96.2^{\mathrm{b}}$ & 1.9 & $\mathrm{p}<0.0001$ \\
Kidney with fat & $107.5^{\mathrm{b}}$ & $127.8^{\mathrm{a}}$ & $131.2^{\mathrm{a}}$ & $128.0^{\mathrm{a}}$ & 2.9 & $\mathrm{P}<0.0001$ \\
Reticulo-rumen & $327.9^{\mathrm{c}}$ & $435.1^{\mathrm{ab}}$ & $444.4^{\mathrm{a}}$ & $400.7^{\mathrm{b}}$ & 12.5 & $\mathrm{p}<0.0001$ \\
Omasum-abomasum & $93.7^{\mathrm{c}}$ & $151.5^{\mathrm{ab}}$ & $158.1^{\mathrm{a}}$ & $144.4^{\mathrm{b}}$ & 3.4 & $\mathrm{P}<0.0001$ \\
Large and small intestine & $449.6^{\mathrm{c}}$ & $576.8^{\mathrm{a}}$ & $567.9^{\mathrm{ab}}$ & $532.4^{\mathrm{b}}$ & 13.4 & $\mathrm{p}<0.0001$ \\
Abdominal fat & $30.2^{\mathrm{c}}$ & $106.1^{\mathrm{a}}$ & $98.7^{\mathrm{ab}}$ & $90.3^{\mathrm{b}}$ & 4.7 & $\mathrm{P}<0.0001$ \\
Testicle & $119.1^{\mathrm{b}}$ & $138.9^{\mathrm{a}}$ & $140.8^{\mathrm{a}}$ & $129.3^{\mathrm{ab}}$ & 3.6 & $\mathrm{P}<0.05$ \\
TEO & $2797.5^{\mathrm{c}}$ & $3603.8^{\mathrm{a}}$ & $3624.2^{\mathrm{a}}$ & $3350.1^{\mathrm{b}}$ & 66.9 & $\mathrm{p}<0.0001$ \\
\hline
\end{tabular}

a, b, c Means with $\mathrm{P}<0.05$ values across rows are significantly different, $\mathrm{ns}=$ Non significantly different, $\mathrm{SEM}=\mathrm{Standard}$ error of mean, $\mathrm{T} 1=$ No mineral supplement, $\mathrm{T} 2=1 \%$ salt, $\mathrm{T} 3=1 \%$ mineral mix and $\mathrm{T} 4=2 \%$ bole soil, $\mathrm{TEO}=$ Total edible offals.

body weight, hot carcass, sternum, hind leg, foreleg and empty body weight were higher in mineral supplemented groups than unsupplemented ones (Table 5).

\section{Edible offal components}

The current study findings showed that the supplementation of minerals for the sheep had a significant effect on almost all edible offal components (Table 6).

\section{Non edible offals}

The findings of the current study showed that animals supplemented with minerals showed significant impact on weight of blood, gut content, spleen, esophagus and skin with feet, lung and total non-edible offals (Table 7).

\section{Partial budget analysis}

The high profit obtained in T2 is due to the lower cost of buying 
The Role of Bole (Lake Soil) as a Mineral Supplement to Arsi-Bale Sheep Fed Natural Grass Hay and Concentrate Supplement

Table 7: Total non-edible offals in growing Arsi-Bale sheep supplemented with bole soil.

\begin{tabular}{|c|c|c|c|c|c|c|}
\hline \multirow{2}{*}{ Non edible offals $(\mathrm{g})$} & \multicolumn{4}{|c|}{ Treatments } & \multirow{2}{*}{ SEM } & \multirow{2}{*}{$P$ value } \\
\hline & $\mathrm{T} 1$ & T2 & T3 & T4 & & \\
\hline Skin with feet & $1463.8^{b}$ & $1724.2^{\mathrm{a}}$ & $1759.5^{\mathrm{a}}$ & $1632.2^{\mathrm{a}}$ & 43.9 & $P<0.05$ \\
\hline Spleen & $60.9^{b}$ & $68.1^{a}$ & $65.6^{\mathrm{ab}}$ & $63.49^{\mathrm{ab}}$ & 1.6 & $P<0.05$ \\
\hline Penis & $27.3^{b}$ & $33.9^{a}$ & $33.2^{\mathrm{a}}$ & $34.1^{\mathrm{a}}$ & 1.0 & $P<0.001$ \\
\hline Lung & $175.5^{b}$ & $204.6^{a}$ & $207.2^{\mathrm{a}}$ & $210.9^{a}$ & 5.5 & $P<0.05$ \\
\hline Trachea & $43.6^{b}$ & $52.6^{a}$ & $52.2^{a}$ & $44.7^{b}$ & 1.8 & $P<0.05$ \\
\hline Esophagus & 24.9 & 26.5 & 26.0 & 25.60 & 0.9 & ns \\
\hline Gall bladder & 8.2 & 7.9 & 7.5 & 7.2 & 0.4 & ns \\
\hline Gut content & $4055.8^{c}$ & $5942.5^{a}$ & $6203.3^{a}$ & $4623.2^{\mathrm{b}}$ & 144.4 & $P<0.0001$ \\
\hline Blood & $698.4^{c}$ & $873.8^{a}$ & $865.0^{a}$ & $761.3^{b}$ & 18.4 & $P<0.0001$ \\
\hline Urinary bladder & 32.1 & 40.1 & 34.7 & 33.6 & 2.9 & ns \\
\hline TNEO & $6605.7^{c}$ & $8994.3^{a}$ & $9274.0^{\mathrm{a}}$ & $7453.1^{\mathrm{b}}$ & 194.9 & $P<0.0001$ \\
\hline
\end{tabular}

a, $b, c$ Means with $\mathrm{P}<0.05$ values across rows are significantly different, $n s=$ Non significantly different, SEM= Standard error of mean, $\mathrm{T} 1=$ No mineral supplement, $\mathrm{T} 2=1 \%$ salt, $\mathrm{T} 3=1 \%$ mineral mix and $\mathrm{T} 4=2 \%$ bole soil, $\mathrm{TNEO}=$ Total non-edible offals.

Table 8: Partial budget analysis in growing Arsi-Bale sheep supplemented with bole soil.

\begin{tabular}{|c|c|c|c|c|}
\hline \multirow{2}{*}{ Parameters } & \multicolumn{4}{|c|}{ Treatments } \\
\hline & T1 & T2 & T3 & $\mathrm{T} 4$ \\
\hline Sheep purchase price (ETB/head) & 381.7 & 383.3 & 382.5 & 378.3 \\
\hline Hay price $(E T B / h e a d)$ & 49.8 & 61.8 & 64.2 & 55.6 \\
\hline Total hay offered $(\mathrm{kg} / \mathrm{head})$ & 50.6 & 57.8 & 56.9 & 55.9 \\
\hline Concentrate price (ETB/head) & 148.4 & 148.4 & 148.4 & 148.4 \\
\hline Total concentrate consumed (kg/head) & 27 & 27 & 27 & 27 \\
\hline Mineral purchase price (ETB/head) & - & 3.0 & 113.4 & - \\
\hline Mineral consumed(kg/head) & - & 0.27 & 0.27 & 0.54 \\
\hline Gross return (ETB/head) & 288.3 & 393.3 & 399.2 & 315.5 \\
\hline Total variable cost (ETB/head) & 293 & 308.1 & 420.8 & 298.8 \\
\hline Net return (ETB/head) & -4.7 & 85.2 & -21.6 & 16.2 \\
\hline$\Delta \mathrm{GR}$ & - & 105 & 110.8 & 26.7 \\
\hline$\Delta T V C$ & - & 15.1 & 127.8 & 5.8 \\
\hline$\Delta \mathrm{NR}$ & - & 89.9 & -16.9 & 20.85 \\
\hline MRR $\Delta \mathrm{NI} / \Delta \mathrm{TVC}$ & - & 5.9 & -0.13 & 3.58 \\
\hline
\end{tabular}

ETB= Ethiopian birr, $\Delta \mathrm{GR}=$ Change in gross return, $\Delta \mathrm{TVC}=$ Change in total variable cost, $\Delta \mathrm{NR}=$ Change in net return, MRR= Marginal rate of return, $\mathrm{T} 1=$ No mineral supplement, $\mathrm{T} 2=1 \%$ salt, $\mathrm{T} 3=1 \%$ mineral mix and $\mathrm{T} 4=2 \%$ bole soil.

salt as compared to T3. The higher profit also obtained in T4 is due to zero cost of bole soil, which resulted in a higher selling price as compared to T1 and T3. On the other hand, the values of MRR of the present study were positive for T2 and T4. The MRR showed that each additional unit of one ETB per sheep cost increment resulted in one ETB and additional of 5.9 and 3.6 ETB benefit from T2 and T4 groups respectively (Table 8).

\section{CONCLUSION}

Bole soil supplementation had potentially highest effect on feed intake, live weight change and carcass characteristics of Arsi-Bale sheep than non-supplemented groups. The present study also revealed that supplementation of minerals improved the total weight gain of sheep over the control treatment. The performance of animals supplemented with bole soil was inferior to those supplemented with common salt and commercial mineral mix. With regard to the economic benefits, sheep supplemented with bole soil and salt returned high net income in comparison to treatments. Therefore, bole soil and salt are highly recommended to farmers for their animals as a mineral supplement.

\section{REFERENCES}

Adugna T. (2008). Feed Resources and Feeding Management. A Manual for Feedlot Operators and Development Workers. Addis Ababa, Ethiopia. pp: 8-35.

AOAC. (1995). Official Methods of Analysis. $16^{\text {th }}$ ed. AOAC Inc. Arlington, VA, USA, pp: 1298.

Brown, L., Hindmarsh, R. and Mcgregor, R. (2001). Dynamic Agricultural Book Three, $2^{\text {nd }}$ edition. McGraw-Hill Book Company, Sydney.

Fazlallah, A. and Shahab, M. (2015). Mineral dietary supplement effects on weight performance and physical characteristics of the components of grazing sheep carcasses. Biological Forum-An International Journal. 7(1): 137-141. 
Girma, H., Getachew, A. and Mengistu, U. (2014). Effect of different proportion of malted oat grain and noug seed cake supplementation on digestibility and performance of Arsibale sheep fed grass hay basal diet. Int. J. of Appllied Sci. Engr. 2(2): 28-36.

Hungate, R.E. (1966). The Rumen and its Microbes. $3^{\text {rd }}$ ed. Academic Press, New York HDAB. Humbo District Agricultural Beruea.

McDonald, P., Edwards, R.A., Greanhalgh, J.F.D. and Morgan, C.A. (2002). Animal Nutrition. $6^{\text {th }}$ ed. Ashford Color Press, Gosport, pp: 693.

McDowell, L.R. (2003). Minerals in Animal and Human Nutrition. $2^{\text {nd }}$ ed. Academic Press, USA. Pp 660.

McDowell, L.R., Conard, J.H., Ellis, G.L. and Loosli, J.K. (1983). Minerals for Grazing Ruminants in Tropical Regions. Department of Animal Science Center for Tropical Agriculture, University of Florida, Gainesville, Florida. 87 p.

Mehlich, A. (1984). Mehlich-3 soil test extractant: A modification of Mehlich-2 extractant. Commun. Soil Sci. Plant Anal. 15(12): 1409-1416.

Muluken Z, Yisehak, K. and Mohammed, Y. (2015). The comparative nutrient utilization and economic efficiency of mineral supplements with concentrates in sheep. European J. of Applied Sci. 7(5): 226-234.

Nega, T., Pravee, V., Pornsri, C. and Suwapong, S. (2006). Milk yield and milk compositions of lactating cows fed hay and concentrate supplement with/without cottonseed cake and/or Bole (Lake soil). Kasetsart J. (Nat Sci). 40: 657-667.

Purchas, R.W. (1978). Some effects of nutrition and castration on meat production from sufflok cross lambs (Border licesterRomney cross). N.Z.J. Agricultural Sci. 21: 367-376.

Ranjbari, A.R. and Rasti, M. (2000). The Effect of Mineral Supple-mentation on Weight and Carcass Components of Lambs in Grasslands of Esfahan Province. The Final Report of Research Project in Agricultural and Natural Resources Research and Education of Kohgilooye-va-Booyer-Ahmad Province.
SAS. (2008). SAS/STAT Guide to Personal Computers, Version 9.1. institute Inc., NC. USA.

Shewangzaw, A., Tegegne, F. and Mekuriaw, Z. (2013). Effect of different levels of dietary bole (Lake Soil) inclusion on feed intake, milk yield and composition of Holstein Friesian cows. Int. J. of Agricultural Biosci. 2(6): 377-382.

Shirley, L.R. (1986). Nitrogen and Energy Nutrition of Ruminants. $1^{\text {st }}$ ed. Acadamic Press Inc. New York.

Sisay, T., Vijchulata, P., Chairatanayuth, P., Swasdiphanich, S. (2007). Effects of natural mineral soils on body weight and liver minerals of black head Somali sheep in Ethiopia. Kasetsart J. (Nat. Sci.). 41: 288-299.

Upton, M. (1979). Farm Management in Africa: The Principle of Production and Planning. Oxford University Press, UK, pp: 282-298.

Van Soest, P.J., Robertson, J.B. and Lewis, B.A. (1991). Methods for dietary fiber neutral detergent fiber and non starch polysaccharides in relation to animal nutrition. J. of Dairy Sci. 74: 3583-3599.

Van Soest, P.J., Robertson, J.B. (1985). Methods of analysis of dietary neutral detergent fiber and non-starch polysaccharides in relation to animal nutrition. J. of Dairy Sci. 74: 35853597.

Van Soest, P.J. (1982). Nutritional Ecology of the Ruminant. Corvallis, Oregon, USA, pp: 374.

Vijchulata, P. (1995). Blood plasma minerals and fertility of dairy cows in Central Thailand. Asian-Australasian J. Anim. Sci. 8(3): 131-137.

White, C.L. (1992). A multi element supplement for grazing sheep intake, mineral status and production response. Aus. J. Agri. Res. 43: 795-808. 